\title{
PENAMBAHAN ADITIF PRESTONE, REDEX DAN BAHAN BAKAR SOLAR TERHADAP PRESTASI MESIN DIESEL, TORSI, DAYA, DAN KONSUMSI BAHAN BAKAR SPESIFIK
}

\author{
Oleh : \\ M. Yunus dan Indriyani \\ (Dosen Teknik Mesin Universitas Sang Bumi Ruwa Jurai)
}

\begin{abstract}
ABSTRAK
Melihat begitu banyak pengguna kendaraan bermotor yang sebagian besar bahan bakarnya minyak bumi, maka dari itu dapat dikhawatirkan minyak bumi akan habis dalam jangka waktu tertentu. Salah satu perlakuan khusus yang diberikan pada bahan bakar untuk meningkatkan unjuk kerja mesin diesel adalah dengan menambahkan aditif pada bahan bakar.

Penelitian dilaksanakan di Laboratorium Teknik Mesin Universitas Lampung. Alat ukur yang digunakan dalam penelitian ini Tec Quipment TD 114 sebagai pengukur torsi, stopwatch dan tachometer sebagai pengukur putaran mesin. Bahan yang digunakan dalam penelitian ini adalah aditif A (Prestone), B (Redex) dan bahan bakar solar.

Dari seluruh penelitian telah dilakukan, maka dapat dilihat pengaruh penambahan aditif bahan bakar terhadap prestasi mesin diesel. Jumlah aditif 0,8\% A (Prestone) yang ditambahkan pada bahan bakar, sangat mempengaruhi tingkat prestasi mesin diesel dibandingkan dengan bahan bakar solar murni meliputi torsi, daya dan konsumsi bahan bakar.

Dari dua macam aditif yang ditambahkan, persentase kenaikan setelah dilakukan uji laboratorium pada putaran tertinggi adalah : Pada penambahan 0,4\% A (Prestone), torsi $2,9 \%$, daya $2,6 \%$, konsumsi bahan bakar 1,6\%. Pada penambahan $0,8 \%$ A (Prestone), torsi $5,7 \%$, daya $5,5 \%$, konsumsi bahan bakar $4,3 \%$. Pada penambahan $0,1 \%$ B (Redex), torsi $1,5 \%$, daya $1,1 \%$, konsumsi bahan bakar $0,9 \%$. Pada penambahan $0,5 \%$ B (Redex), torsi $4,1 \%$, daya $4,0 \%$, konsumsi bahan bakar $3,8 \%$.
\end{abstract}

keywords : aditif, mesin diesel, torsi, daya, bahan bakar spesifik.

\section{ADDING ADDITIVES PRESTONE, REDEX AND SOLAR ON DIESEL ENGINE PERFORMANCE, TORQUE, POWER, AND SPECIFIC FUEL CONSUMPTION}

\author{
By: \\ M. Yunus dan Indriyani \\ (Lecturer of Mechanical Engineering Faculty, University Sang Bumi Ruwa Jurai)
}

\begin{abstract}
Analyzing to motor cycle user were mostly consuming fuel oil, then it is feared petroleum will be exhausted within a certain period. One of the special treatment which given to fuel to enhance the performance of the diesel engine is to add an additive to the fuel. Research conducted at the Laboratory of Mechanical Engineering, University of Lampung.

Measuring instrument used in this study Tec Quipment TD 114 as a torque gauge, tachometer as a stopwatch and measuring the spin machine. The materials used in this
\end{abstract}


study is additive A (STP), B (Redex) and diesel fuel. Based on the research, it can be seen on the effect of the addition of fuel additives on the performance of diesel engines.

A number of additive $0.8 \%$ (STP) is added to the fuel, greatly affect the level of achievement of diesel engines compared to pure diesel fuel include torque, power and fuel consumption. Of the two kinds of additives are added, the percentage increase after a laboratory test at the highest rotation is: In addition $0.4 \%$ A (STP), a torque of $2.9 \%, 2.6 \%$ power, fuel consumption of $1.6 \%$.

In addition $0.8 \% \mathrm{~A}(\mathrm{STP})$, a torque of $5.7 \%, 5.5 \%$ power, fuel consumption is $4.3 \%$. In addition $0.1 \% \mathrm{~B}$ (Redex), a torque of $1.5 \%, 1.1 \%$ power, and fuel consumption is $0.9 \%$. In addition $0.5 \%$ B (Redex), torque $4.1 \%$, power $4.0 \%$, fuel consumption of $3.8 \%$

keywords: additives, diesel engine performance, torque, power and specific fuel

\section{PENDAHULUAN}

Dengan perkembangan ilmu pengetahuan saat ini, maka efisiensi energi perlu dikembangkan mengingat sumber energi khususnya minyak bumi sudah semakin menipis. Melihat begitu banyak pengguna kendaraan bermotor yang sebagian besar bahan bakarnya minyak bumi, dikhawatirkan minyak bumi akan habis dalam jangka waktu tertentu. Dari masalah di atas maka efisiensi yang diinginkan meliputi daya yang dihasilkan besar, konsumsi bahan bakar rendah. Salah satu perlakuan khusus yang diberikan pada bahan bakar untuk meningkatkan efisiensi mesin adalah dengan memberikan aditif pada bahan bakar. Penggunaan zat aditif pada bahan bakar kendaraan bermotor adalah untuk meningkatkan unjuk kerja kendaraan, dan untuk menghemat laju konsumsi bahan bakar. Penggunaan zat aditif itu sendiri selain untuk penghematan dan penambah daya kerja, juga untuk menjaga kondisi mesin agar tetap baik. Untuk mendapatkan kondisi kendaraan seperti tersebut diatas maka dilakukan pencampuran zat aditif tertentu ke dalam bahan bakar kendaraan.

Untuk itu perlu dilakukan suatu pengujian secara laboratorium untuk membuktikan bahwa penggunaan zat aditif dapat menambah unjuk kerja motor diesel dan menghemat laju konsumsi bahan bakar. Pengujian dilakukan terhadap unjuk kerja motor bakar, yang meliputi: torsi sebagai fungsi putaran poros, daya sebagai fungsi putaran poros, konsumsi bahan bakar sebagai fungsi putaran poros dan konsumsi bahan bakar spesifik sebagai fungsi putaran poros. Diharapkan dari hasil pengujian diperoleh informasi ilmiah tentang pengaruh penggunaan zat aditif tersebut terhadap unjuk kerja motor diesel.

Penelitian dilakukan dengan menggunakan motor bakar empat langkah satu silinder yang menggunakan bahan 
bakar solar. Dari penelitian ini adalah untuk mengetahui pengaruh penggunaan zat aditif pada bahan bakar terhadap unjuk kerja motor bakar diesel 4-Tak, yang meliputi pengukuran :

Torsi, Daya, Konsumsi bahan bakar dan Konsumsi bahan bakar spesifik. Permasalahan yang timbul adalah seberapa besar pengaruh penambahan aditif pada bahan bakar terhadap perubahan unjuk kerja mesin diesel. Pada mesin pembakaran dalam (Internal Combustion Engine) mesin diesel bahan bakar diinjeksikan kedalam ruang bakar sehingga terbakar dalam udara dan mengkonversikan energi kimianya menjadi energi mekanis.

Pembakaran menimbulkan panas dan menghasilkan tekanan, kemudian menghasilkan tenaga mekanik pada mesin diesel. Udara murni di masukan kedalam silinder dan dikompresikan oleh torak pada tekanan $18-25 \mathrm{~kg} / \mathrm{cm}^{2}$ bahan bakar dinyalakan oleh udara kompresi dan terbakar dengan cepat di dalam ruang bakar. Suhu udara naik hingga antara $1200-1600^{\circ} \mathrm{C}$ dan tekanan $30-40$ $\mathrm{kg} / \mathrm{cm}^{2}$, kemudian tekanan tersebut menekan torak kebawah. Penambahan aditif pada bahan bakar diharapkan untuk meningkatkan prestasi mesin diesel, dengan besar penambahan yang telah ditentukan :

\section{Bahan dan Alat}

Alat - alat yang digunakan pada penelitian ini adalah

1. Mesin yang diuji motor diesel 4 tak 1 silinder, merk/type Robin -Fuji DY23D

2. Bahan aditif yang digunakan adalah $\mathrm{A}$ (Prestone) \& B (Redex)

3. Besar aditif yang ditambahkan $0,1 \%$ dan $0,5 \%$ B (Redex), 0,4 \% dan $0,8 \%$ A (Prestone)

4. Unjuk kerja mesin yang diamati meliputi pengukuran sebagai berikut : Torsi (N.m), Daya (kW), Konsumsi bahan bakar spesifik $(\mathrm{kg} / \mathrm{kWh})$ dan Konsumsi bahan bakar (ml/detik)

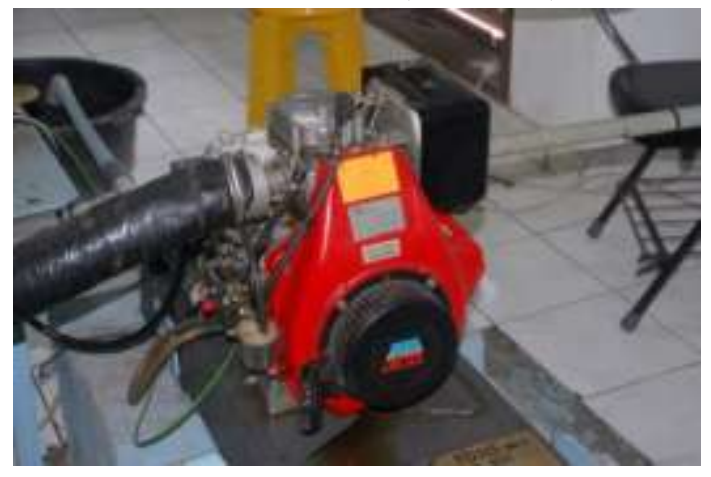

\section{Gambar 1.1 Motor Diesel 4-Langkah}

$$
\text { Robin - Fuji DY23D Air Cooler }
$$

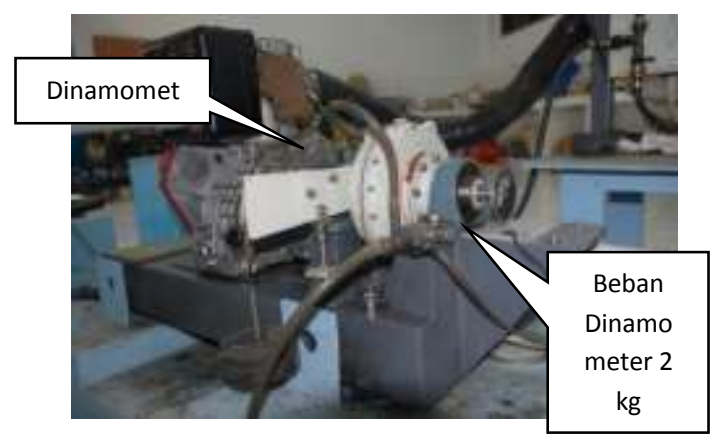

Gambar 1.2 Dinamometer Hidraulik 


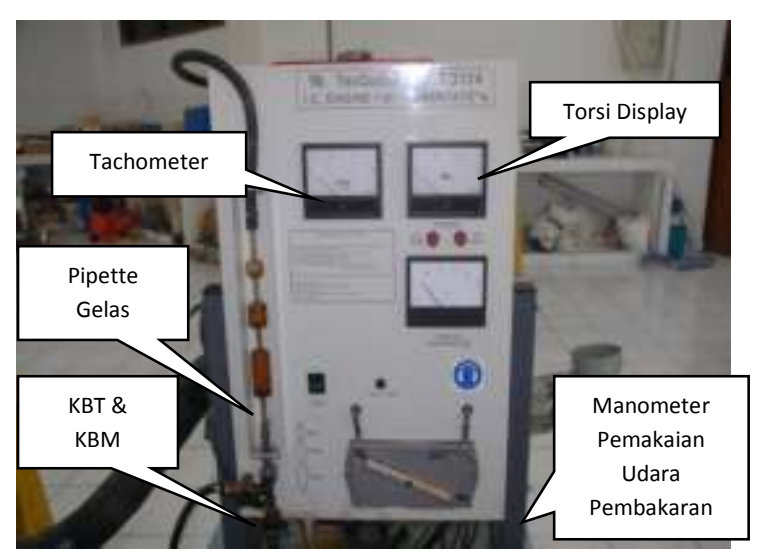

Gambar 1.3 Unit Instrumen Tec

Quipment Td 114

\section{BAHAN DAN METODE}

Dalam penelitian ini sebagai variable bebas adalah variasi persentase penambahan aditif pada bahan bakar, dengan besar persentase penambahan $\mathrm{A}$ (Prestone) $0,4 \% \& 0,8 \%, \mathrm{~B}$ (Redex) $0,1 \%$ $\& 0,5 \%$. Sebagai variable terikat dalam penelitian ini adalah Prestasi Mesin. Dalam penelitian ini sebagai variable kontrol adalah sistem pelumasan, sistem pendingin dan suhu kerja motor. Penambahan aditif bahan bakar solar dapat meningkatkan prestasi mesin diesel.

\subsection{Alat-alat Yang Digunakan}

1. Tachometer. Alat ini digunakan untuk mengukur putaran mesin.

2. Stopwatch. Digunakan untuk mengukur waktu .

3. Dinamo meter Hidroulik. Digunakan untuk mengukur Torsi
4. Unit Instrumentasi TD 144.

Digunakan untuk pengukuran putaran mesin, torsi, temperatur gas buang, laju pemakaian bahan bakar.

\section{Spesifikasi Motor yang Digunakan}

Pengujian pada percobaan ini dilakukan terhadap 1 unit motor diesel dengan spesifikasi : Motor Diesel 4Langkah

Merk/Type : Robin - Fuji DY23D

Jenis : Motor Diesel 4-Tak, 1 silinder

Volume Langkah Torak : $230 \mathrm{~cm}^{3}$

Langkah Torak : $60 \mathrm{~mm}$

Diameter Silinder : $70 \mathrm{~mm}$

Perbandingan Kompresi : $21: 1$

Torsi Maksimum:10,5Nm pada $2200 \mathrm{rpm}$ Daya Engkol Maksimum : 3,5 kW pada $3600 \mathrm{rpm}$

Putaran Maksimum Dianjurkan: 3600rpm Posisi Valve : Overhead (OHV)

Waktu Injeksi Bahan Bakar : $23^{0}$ BTDC (Before Top Death Centre)

Berat : $26 \mathrm{~kg}$

\subsection{Tahapan Percobaan terbagi 3} yaitu:

1. Persiapan. Sebelum melakukan percobaan yang perlu dilakukan adalah : Menyiapkan peralatan/alat ukur yang akan digunakan. Melakukan pemerikasaan kondisi mesin atau tune up. Mengisi bahan bakar. Menghidupkan mesin. 
2. Prosedur Pengujian. Motor Diesel 4Langkah. Catat temperatur ruangan Laboratirum. Pastikan bahan bakar selalu ada dalam pipet gelas. Putar katub KBM pada posisi maksimum (posisi horizontal). Gantungkan beban pada Dinamometer sebesar $2 \mathrm{~kg}$. Geser perlahan-lahan tungkai gas hingga putaran mesin terbaca pada tachometer $\pm 3500 \mathrm{rpm}$. Tunggu hingga bacaan Torsi dan putaran mesin terlihat stabil. Setelah bacaan Torsi stabil, isikan bahan bakar melewati batas NOL pada pipette gelas dengan membuka katup KBT, kemudian tutup kembali katup KBT tersebut. Hitung dan cacat waktu pemakaian untuk $8 \mathrm{ml}$ bahan bakar. Pada waktu yang bersamaan, catat juga Putaran mesin, Torsi, Temperatur gas buang, dan Pemakaian udara pembakaran pada manometer $\mathrm{mmH}_{2} \mathrm{O}$. Pastikan air umpan Dinamometer selalu mengalir, yaitu dengan memeriksa keluarannya. Periksa bahwa temperatur air yang mengalir keluar Dinamometer di bawah $80^{\circ} \mathrm{C}$. Jika temperaturnya lebih tinggi, tingkatkan aliran airnya untuk mendinginkan seal bantalan Dinamometer tersebut. Pilih putaran mesin berikutnya, caranya tarik perlahan-lahan tungkai gas hingga putaran mesin turun. Tunggulah sampai putaran mesin stabil sebelum mengambil/mencatat hasil pengujian yang lain. Jika dinamometer terlalu sensitif dalam mendapatkan putaran yang diinginkan, ini harus dibantu dengan menutup sebagian drain tapnya, jangan ditutup total. Ulangi langkah ke-10 hingga diperoleh 5 kondisi putaran mesin. (pilih 3 putaran mesin yaitu 3500, 2750, dan 2000 . Lakukan pengujian berikutnya pada kondisi putaran mesin yang sama, tapi beban tergantung yang lain.

3. Menghentikan Mesin. Kurangi aliran air yang melintasi Dinamometer hingga menetes. Geser tungkai gas sampai mesin berputar pada putaran idle. Biarkan mesin berputar beberapa menit. Tutup tungkai gas untuk mematikan mesin tersebut. Tutup katup KBT. Lepaskan arus listrik ke Unit Instrumentasi TD114.

Setelah persiapan dan pelaksanaan percobaan dimulai pengambilan data percobaan :

1. Pengujian dengan kondisi bahan bakar belum ditambah aditif. Konsumsi bahan bakar dilakukan pengujian pada putaran $2000 \mathrm{rpm}$, $2750 \mathrm{rpm}, 3500 \mathrm{rpm}$. 
2. Pengujian dengan kondisi bahan bakar ditambah aditif. Konsumsi bahan bakar dilakukan pengujian pada putaran $2000 \mathrm{rpm}, 2750 \mathrm{rpm}$, $3500 \mathrm{rpm}$.

\subsection{Analisa Data}

Data-data diperoleh dari pengujian kemudian dianalisis untuk mengetahui pengaruh penambahan aditif pada bahan bakar diesel terhadap unjuk kerja mesin diesel dan konsumsi bahan bakar.

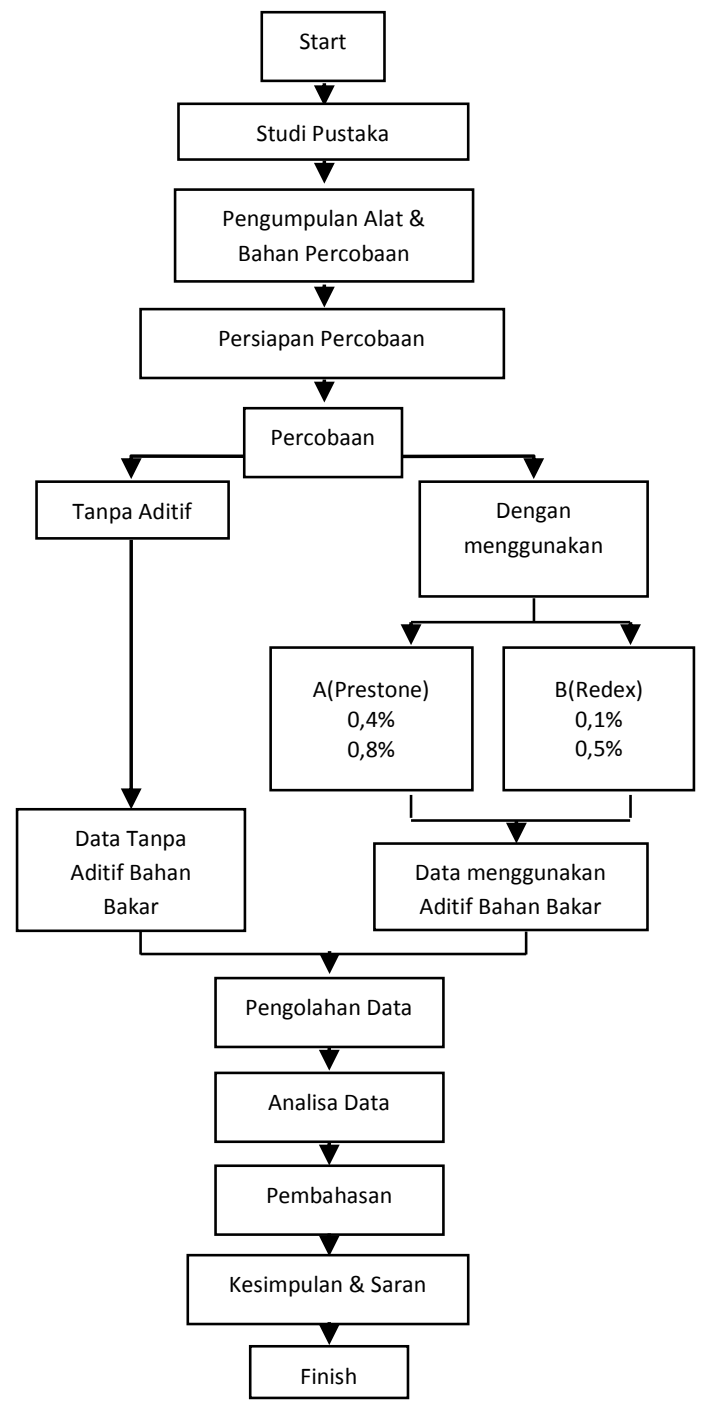

Gambar 2.1. Diagram Alir Penelitian
III. HASIL DAN PEMBAHASAN

\section{A. HASIL UJI COBA}

\subsection{Hasil Pengujian}

Konsumsi bahan bakar sebanyak $8 \mathrm{ml}$, maka didapat lama waktu untuk menghabiskan jumlah bahan bakar tersebut. Sebelum penambahan aditif dan sesudah penambahan aditif, dengan beberapa variasi persentase penambahan aditif dari dua macam aditif yang digunakan A (Prestone) dan B (Redex). Data dapat dilihat 3.1, 3.2, 3.3, 3.4 dan 3.5

Tabel 3.1. Hasil uji konsumsi b bakar sebelum ditambah aditif bahan bakar (solar murni).

\begin{tabular}{|c|c|c|c|c|c|}
\hline \multirow{2}{*}{ No. } & \multirow{2}{*}{$\begin{array}{c}\text { Putaran } \\
(\text { Rpm) }\end{array}$} & $\begin{array}{c}\text { Percoba } \\
\text { an 1 }\end{array}$ & $\begin{array}{c}\text { Percoba } \\
\text { an 2 }\end{array}$ & $\begin{array}{c}\text { Percoba } \\
\text { an 3 }\end{array}$ & Rata-rata \\
(detik)
\end{tabular}

Tabel 3.2. Hasil uji konsumsi bh bakar sesudah ditambah aditif bh bakar A (Prestone) 0,4\%.

\begin{tabular}{|c|c|c|c|c|c|}
\hline \multirow{2}{*}{ No. } & \multirow{2}{*}{$\begin{array}{c}\text { Putaran } \\
(\mathbf{R p m})\end{array}$} & $\begin{array}{c}\text { Percoba } \\
\text { an 1 }\end{array}$ & $\begin{array}{c}\text { Percoba } \\
\text { an 2 }\end{array}$ & $\begin{array}{c}\text { Percoba } \\
\text { an 3 }\end{array}$ & $\begin{array}{c}\text { Rata-rata } \\
\text { (detik) }\end{array}$ \\
\cline { 3 - 5 } & & 120,11 & 120,18 & 120,16 & 120,15 \\
\hline 1 & 2000 & 83,16 & 83,19 & 83,20 & 83,18 \\
\hline 2 & 2750 & 51,18 & 51,13 & 51,19 & 51,16 \\
\hline 3 & 3500 & &
\end{tabular}


Tabel 3.3. Hasil uji konsumsi b bakar sesudah ditambah aditif $\mathrm{b}$ bakar $\mathrm{A}$ (Prestone) 0,8\%.

\begin{tabular}{|c|c|c|c|c|c|}
\hline \multirow{2}{*}{ No. } & \multirow{2}{*}{$\begin{array}{c}\text { Putaran } \\
(\mathbf{R p m})\end{array}$} & $\begin{array}{c}\text { Percoba } \\
\text { an 1 }\end{array}$ & $\begin{array}{c}\text { Percoba } \\
\text { an 2 }\end{array}$ & $\begin{array}{c}\text { Percoba } \\
\text { an 3 }\end{array}$ & Rata-rata \\
(detik)
\end{tabular}

Tabel 3.4. Hasil uji konsumsi bh bakar sesudah ditambah aditif bh bakar B (Redex) $0,1 \%$.

\begin{tabular}{|c|c|c|c|c|c|}
\hline \multirow[b]{2}{*}{ No. } & \multirow{2}{*}{$\begin{array}{c}\text { Putaran } \\
\text { (Rpm) }\end{array}$} & \multicolumn{3}{|c|}{ Waktu (detik) } & \multirow{2}{*}{$\begin{array}{c}\text { Rata- } \\
\text { rata } \\
\text { (detik) }\end{array}$} \\
\hline & & $\begin{array}{c}\text { Percob } \\
\text { aan } 1\end{array}$ & $\begin{array}{c}\text { Percoba } \\
\text { an } 2\end{array}$ & $\begin{array}{c}\text { Percoba } \\
\text { an } 3\end{array}$ & \\
\hline 1 & 2000 & 119,17 & 119,34 & 119,25 & 119,25 \\
\hline 2 & 2750 & 82,22 & 82,29 & 82,31 & 82,27 \\
\hline 3 & 3500 & $\begin{array}{l}50,81 \\
\end{array}$ & 50,73 & 50,81 & 50,78 \\
\hline
\end{tabular}

Tabel 3.5. Hasil uji konsumsi b bakar sesudah ditambah aditif $\mathrm{b}$ bakar $\mathrm{B}$ (Redex) $0,5 \%$.

\begin{tabular}{|c|c|c|c|c|c|}
\hline \multirow{2}{*}{$\begin{array}{c}\text { No } \\
\cdot\end{array}$} & \multirow{2}{*}{$\begin{array}{c}\text { Putaran } \\
(\text { Rpm) }\end{array}$} & \multicolumn{3}{|c|}{ Waktu (detik) } & Rata- \\
\cline { 3 - 5 } & an 1 & rata \\
n 2 & $\begin{array}{c}\text { aan 3 } \\
\text { (detik) }\end{array}$ \\
\hline 1 & 2000 & 121,14 & 121,12 & 121,15 & 121,14 \\
\hline 2 & 2750 & 84,12 & 84,16 & 84,14 & 84,14 \\
\hline 3 & 3500 & 51,95 & 51,93 & 51,96 & 51,95 \\
\hline
\end{tabular}

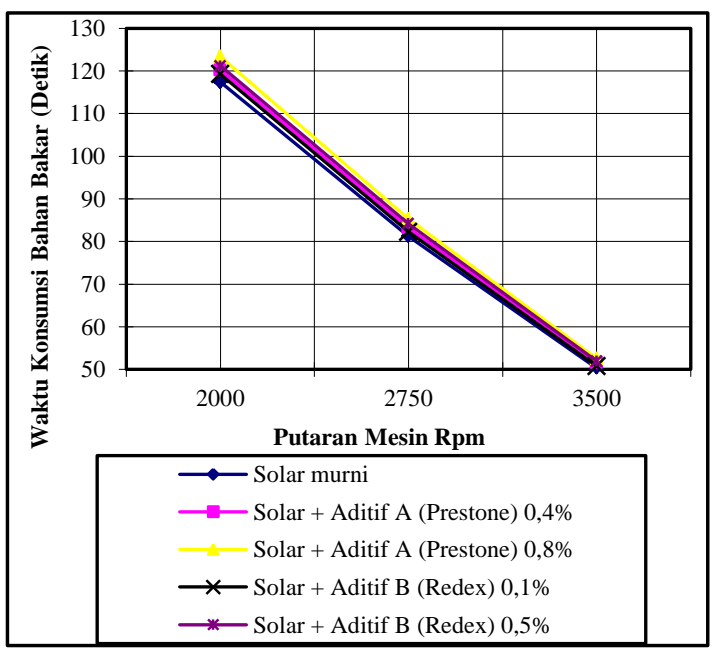

Gambar 3.1. Grafik Hasil Uji Waktu

Konsumsi Bahan Bakar Sebanyak $8 \mathrm{Ml}$.
Dari gambar tersebut menunjukan bahawa semakin besar persentase yang ditambahkan, maka waktu yang dibutuhkan untuk menghabiskan bahan bakar sebanyak $8 \mathrm{ml}$ semakin banyak atau lebih irit dibanding bahan bakar solar murni.

\subsection{Hasil Uji Torsi Pada Alat Ukur Tec Quipment TD 114}

Setelah dilakukan pengujian pada Mesin Diesel Robin-Fuji DY23D, maka didapat hasil uji torsi pada alat ukur Tec Quipment TD 114, dengan konsumsi bahan bakar sebanyak $8 \mathrm{ml}$. Sebelum penambahan aditif dan sesudah penambahan aditif, dengan beberapa variasi persentase penambahan aditif dari dua macam aditif yang digunakan $\mathrm{A}$ (Prestone) dan B (Redex). Data-data tersebut dapat dilihat dalam tabel 3.6, 3.7, 3.8, 3.9, 3.10.

Tabel 3.6. Data Uji Torsi Pada Alat Ukur sebelum ditambah aditif bh bakar (Solar murni).

\begin{tabular}{|c|c|c|c|c|c|}
\hline \multirow{2}{*}{ No. } & \multirow{2}{*}{$\begin{array}{c}\text { Putaran } \\
(\text { Rpm) }\end{array}$} & \multicolumn{3}{|c|}{ Torsi (Nm) } & Rata- \\
\cline { 3 - 5 } & & Percoba & Percoba & Percoba & rata \\
an 2 & an 3 & (Nm) \\
\hline 1 & 2000 & 6,51 & 6,53 & 6,52 & 6,52 \\
\hline 2 & 2750 & 7,12 & 7,13 & 7,14 & 7,13 \\
\hline 3 & 3500 & 7,42 & 7,43 & 7,45 & 7,43 \\
\hline
\end{tabular}


Tabel 3.7. Data Uji Torsi Pada Alat Ukur ditambah aditif bh bakar A (Prestone) $0,4 \%$.

\begin{tabular}{|c|c|c|c|c|c|}
\hline \multirow{2}{*}{ No. } & \multirow{2}{*}{$\begin{array}{c}\text { Putaran } \\
\text { (Rpm) }\end{array}$} & \multicolumn{3}{|c|}{ Torsi (Nm) } & \multirow{2}{*}{ Rata-rata } \\
\cline { 3 - 5 } & & an 1 & $\begin{array}{c}\text { Percoba } \\
\text { an 2 }\end{array}$ & $\begin{array}{c}\text { Percoba } \\
\text { an 3 }\end{array}$ & \\
\hline 1 & 2000 & 6,71 & 6,74 & 6,73 & 6,72 \\
\hline 2 & 2750 & 7,32 & 7,33 & 7,35 & 7,33 \\
\hline 3 & 3500 & 7,64 & 7,65 & 7,67 & 7,65 \\
\hline
\end{tabular}

Tabel 3.8. Data Uji Torsi Pada Alat Ukur ditambah aditif bahan bakar A (Prestone) $0,8 \%$.

\begin{tabular}{|c|c|c|c|c|c|}
\hline \multirow{2}{*}{ No. } & \multirow{2}{*}{$\begin{array}{c}\text { Putaran } \\
\text { (Rpm) }\end{array}$} & $\begin{array}{c}\text { Percoba } \\
\text { an 1 }\end{array}$ & $\begin{array}{c}\text { Percoba } \\
\text { an 2 }\end{array}$ & $\begin{array}{c}\text { Percoba } \\
\text { an 3 }\end{array}$ & Rata-rata \\
(Nm)
\end{tabular}

Tabel 3.9. Data uji torsi pada alat ukur ditambah aditif bahan bakar B (Redex) $0,1 \%$.

\begin{tabular}{|c|c|c|c|c|c|}
\hline \multirow{2}{*}{ No. } & \multirow{2}{*}{$\begin{array}{c}\text { Putara } \\
\text { n }\end{array}$} & \multicolumn{3}{|c|}{ Torsi (Nm) } & \multirow{2}{*}{ Rata-rata } \\
\cline { 3 - 5 } & $(\mathbf{R p m})$ & Percoba & Percoba & Percoba & an 1 \\
an 2 & an 3 & \\
\hline 1 & 2000 & 6,62 & 6,60 & 6,64 & 6,62 \\
\hline 2 & 2750 & 7,23 & 7,22 & 7,21 & 7,22 \\
\hline 3 & 3500 & 7,52 & 7,54 & 7,55 & 7,54 \\
\hline
\end{tabular}

Tabel 3.10. Data uji torsi pada alat ukur ditambah aditif bahan bakar B (Redex) $0,5 \%$.

\begin{tabular}{|l|l|l|l|l|l|}
\hline \multirow{2}{*}{ No. } & \multirow{2}{*}{$\begin{array}{l}\text { Putaran } \\
(\mathbf{R p m})\end{array}$} & $\begin{array}{l}\text { Torsi (Nm) } \\
\text { n 1 }\end{array}$ & $\begin{array}{l}\text { Percobaa } \\
\text { an 2 }\end{array}$ & $\begin{array}{l}\text { Rercobaa } \\
\mathbf{n ~ 3}\end{array}$ & $\begin{array}{r}\text { rata } \\
\text { (Nm) }\end{array}$ \\
\hline 1 & 2000 & 6,78 & 6,76 & 6,79 & 6,78 \\
\hline 2 & 2750 & 7,42 & 7,44 & 7,43 & 7,43 \\
\hline 3 & 3500 & 7,72 & 7,74 & 7,75 & 7,74 \\
\hline
\end{tabular}

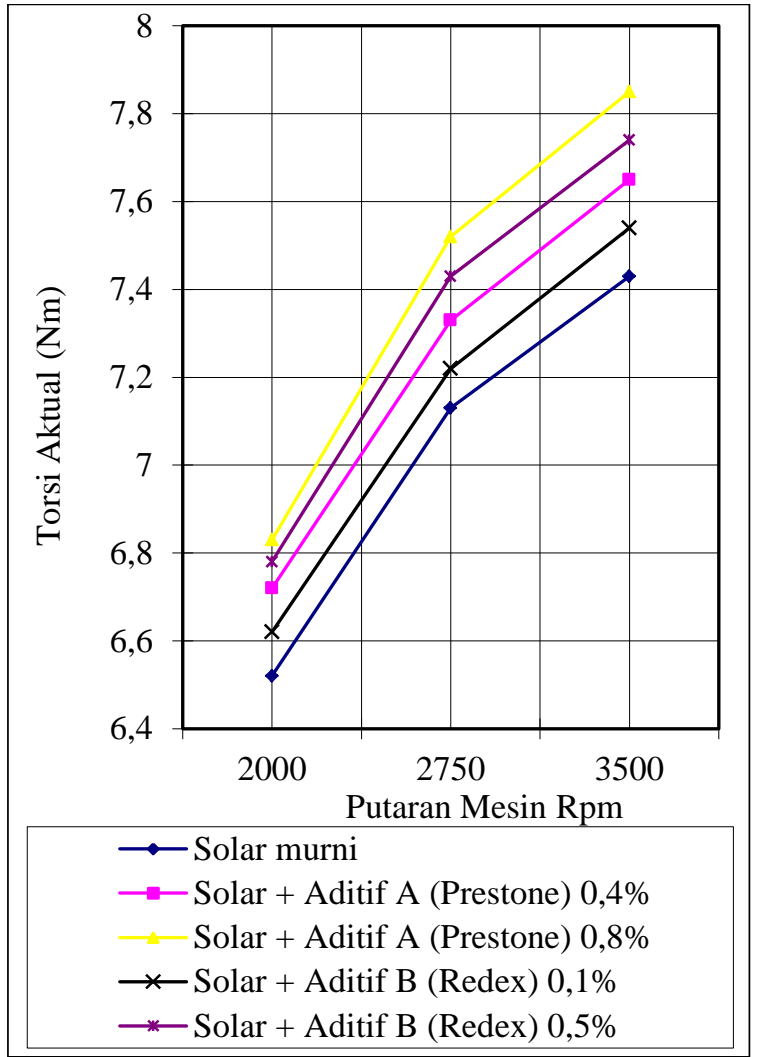

Gambar 3.2. Grafik torsi aktual terhadap putaran mesin.

Dari grafik tersebut menunjukan bahawa semakin besar persentase yang ditambahkan, maka semakin besar torsi aktual yang didapat pada alat ukur Tec Quipment TD 114.

\subsection{Daya Rem (Brake Horse Power)}

Setelah dilakukan pengujian maka didapat daya kuda rem hasil perhitungan pada Mesin Diesel Robin - Fuji DY23D. Sebelum penambahan aditif dan sesudah penambahan aditif, dengan beberapa variasi persentase penambahan aditif dari dua macam aditif yang digunakan A (Prestone) dan B (Redex). Data tersebut dapat dilihat pada tabel 3.11. 
Tabel 3.11. Data Hasil Perhitungan Daya Kuda Rem Mesin.

\begin{tabular}{|c|c|c|c|c|c|c|}
\hline \multirow{2}{*}{ No. } & \multirow{2}{*}{\begin{tabular}{c} 
Putaran \\
Mesin \\
\cline { 4 - 7 }
\end{tabular}} & \multicolumn{2}{|c|}{ Bp ( kg / kW ) Berbagai komposisi Bahan Bakar } \\
\cline { 4 - 7 } & Solar & \multicolumn{2}{|c|}{$\begin{array}{c}\text { Solar + Aditif B } \\
\text { murni }\end{array}$} & \multicolumn{2}{|c|}{$\begin{array}{c}\text { Solar + Aditif A } \\
\text { (Redex) }\end{array}$} & \multicolumn{2}{|c|}{ (Prestone) } \\
\cline { 4 - 7 } & & & $\mathbf{0 , 1 \%}$ & $\mathbf{0 , 5 \%}$ & $\mathbf{0 , 4 \%}$ & $\mathbf{0 , 8 \%}$ \\
\hline 1. & 2000 & 1,37 & 1,38 & 1,41 & 1,40 & 1,42 \\
\hline 2. & 2750 & 2,05 & 2,08 & 2,14 & 2,10 & 2,16 \\
\hline 3. & 3500 & 2,73 & 2,76 & 2,84 & 2,80 & 2,88 \\
\hline
\end{tabular}

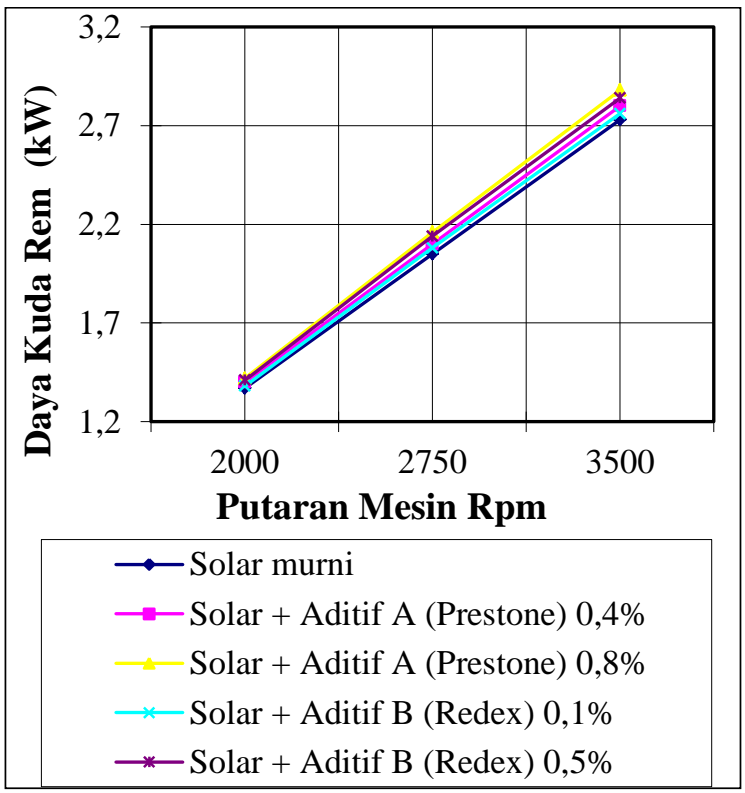

Gambar 3.3. Grafik Daya Rem Hasil Perhitungan Pada Mesin.

Dari gambar grafik tersebut menunjukan bahwa semakin besar persentase penambahan aditif pada bahan bakar, maka semakin besar pula daya kuda rem yang dihasilkan, dari hasil perhitungan.

\subsection{Konsumsi Bahan Bakar Spesifik}

Setelah dilakukan pengujian maka didapat konsumsi bahan bakar spesifik hasil perhitungan pada Mesin Diesel Robin - Fuji DY23D. Sebelum penambahan aditif dan sesudah penambahan aditif, dengan beberapa variasi persentase penambahan aditif dari dua macam aditif yang digunakan A (Prestone) dan B (Redex). Data tersebut dapat dilihat pada tabel 3.12.

Tabel 3.12. Data hasil perhitungan

\begin{tabular}{|c|c|c|c|c|c|c|}
\hline \multirow{2}{*}{ No. } & \multirow{3}{*}{$\begin{array}{c}\text { Putaran } \\
\text { Mesin } \\
\end{array}$} & \multicolumn{4}{|c|}{ Bsfc ( kg / kWh ) Berbagai komposisi Bahan } \\
(Rpm) & \multirow{2}{*}{$\begin{array}{c}\text { Solar } \\
\text { Murni }\end{array}$} & \multicolumn{2}{|c|}{$\begin{array}{c}\text { Solar + Aditif } \\
\text { B (Redex) }\end{array}$} & $\begin{array}{c}\text { Solar + Aditif } \\
\text { A (Prestone) }\end{array}$ \\
\cline { 4 - 7 } & & & $\mathbf{0 , 1 \%}$ & $\mathbf{0 , 5 \%}$ & $\mathbf{0 , 4 \%}$ & $\mathbf{0 , 8 \%}$ \\
\hline 1. & 2000 & 0,15 & 0,14 & 0,14 & 0,14 & 0,13 \\
\hline 2. & 2750 & 0,15 & 0,14 & 0,14 & 0,14 & 0,13 \\
\hline 3. & 3500 & 0,16 & 0,17 & 0,16 & 0,16 & 0,16 \\
\hline
\end{tabular}

konsumsi bahan bakar spesifik.

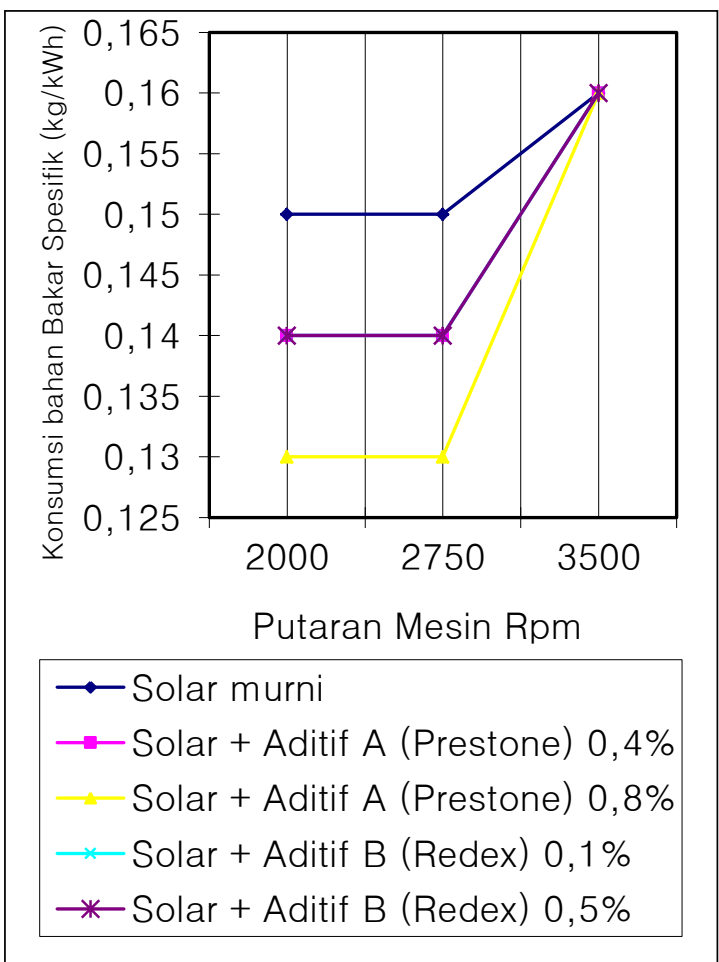

Gambar 3.4. Grafik Konsumsi Bahan

Bakar Spesifik dengan daya yang dihasilkan. 
Dari gambar tersebut dapat dilihat bahwa untuk menghasilkan energi setiap $\mathrm{kW} / \mathrm{jam}$ dibutuhkan bahan bakar lebih sedikit, jika persentase aditif yang ditambahkan pada bahan bakar yaitu pada 0,8\% A(Prestone).

Jika persentase aditif yang ditambahkan pada bahan bakar semakin kecil atau solar murni, maka untuk menghasilkan energi setiap $\mathrm{kW} / \mathrm{jam}$ dibutuhkan bahan bakar semakin banyak.

\subsection{Panas Thermal Efficiency}

Setelah dilakukan pengujian maka didapat efisiensi panas hasil perhitungan pada Mesin Diesel Robin - Fuji DY23D. Sebelum penambahan aditif dan sesudah penambahan aditif, dengan beberapa variasi persentase penambahan aditif dari dua macam aditif yang digunakan $\mathrm{A}($ Prestone) dan $\mathrm{B}($ Redex $)$. Data tersebut dapat dilihat pada tabel 3.13.

Tabel 3.13. Data hasil perhitungan Efisiensi Panas Thermal Efficiency

\begin{tabular}{|c|c|c|c|c|c|c|}
\hline \multirow{2}{*}{ No. } & \multirow{2}{*}{$\begin{array}{c}\text { Putaran } \\
\text { Mesin }\end{array}$} & \multicolumn{4}{|c|}{$\eta$ bth Berbagai komposisi Bahan Bakar } \\
\cline { 4 - 7 } & (Rpm) & \multirow{2}{*}{$\begin{array}{c}\text { Solar } \\
\text { murni }\end{array}$} & \multicolumn{2}{|c|}{$\begin{array}{c}\text { Solar + Aditif } \\
\text { B (Redex) }\end{array}$} & \multicolumn{2}{|c|}{$\begin{array}{c}\text { Solar + Aditif } \\
\text { A (Prestone) }\end{array}$} \\
\cline { 4 - 7 } & & & $\mathbf{0 , 1 \%}$ & $\mathbf{0 , 5 \%}$ & $\mathbf{0 , 4 \%}$ & $\mathbf{0 , 8 \%}$ \\
\hline 1. & 2000 & 0,59 & 0,60 & 0,60 & 0,60 & 0,64 \\
\hline 2. & 2750 & 0,57 & 0,61 & 0,63 & 0,62 & 0,64 \\
\hline 3. & 3500 & 0,52 & 0,50 & 0,52 & 0,53 & 0,52 \\
\hline
\end{tabular}

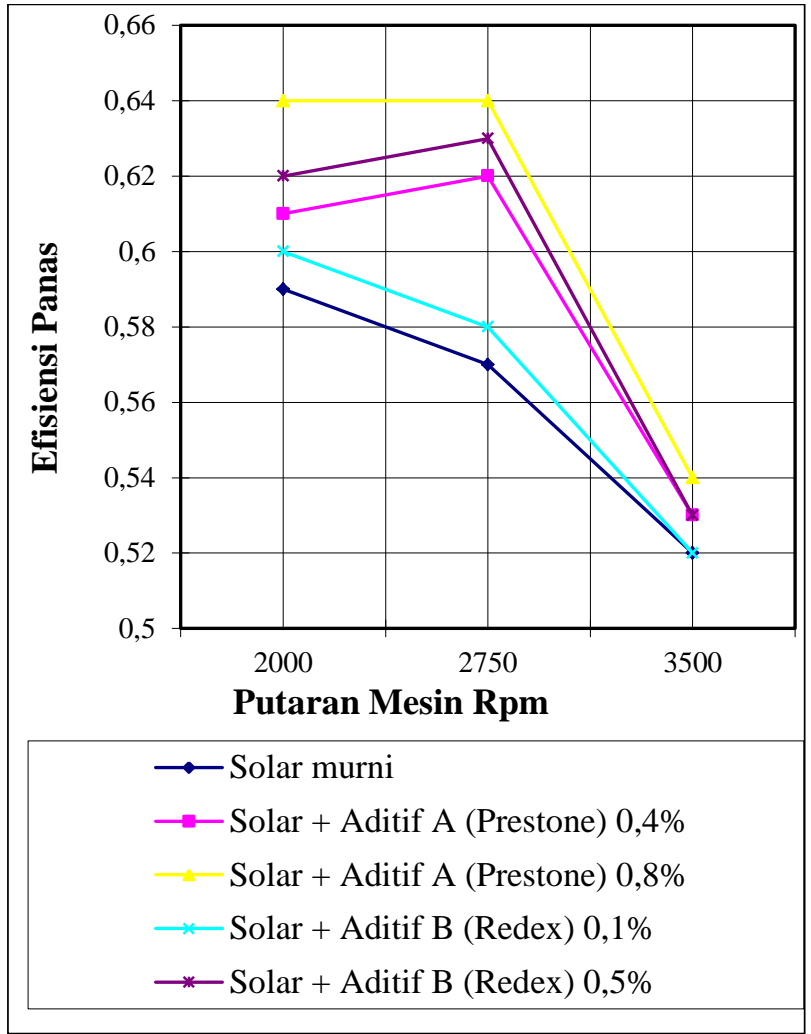

Gambar 3.5. Grafik Efisiensi Panas

Hasil Perhitungan Pada Mesin.

Dari gambar grafik tersebut dapat dilihat bahwa efisiensi panas lebih besar jika aditif yang ditambahkan pada bahan bakar dengan persentase 0,8\%. Pada putaran $2750 \mathrm{Rpm}$, perbedaan efisiensi panas dapat terlihat jelas pada putaran tersebut. Untuk persentase yang lain dari dua macam aditif yang digunakan, efisiensi panas lebih kecil, untuk masingmasing putaran mesin sama.

\subsection{Tekanan Efektif Rata-rata}

Setelah dilakukan pengujian maka didapat tekanan efektif rata-rata $\left(B_{\text {mep }}\right)$ hasil perhitungan pada Mesin Diesel Robin - Fuji DY23D. Sebelum 
penambahan aditif dan sesudah penambahan aditif, dengan beberapa variasi prosentase penambahan aditif dari dua macam aditif yang digunakan $\mathrm{A}($ Prestone) dan B(Redex). Data tersebut dilihat tabel 3.14.

Tabel 3.14. Data hasil perhitungan tekanan efektif rata-rata.

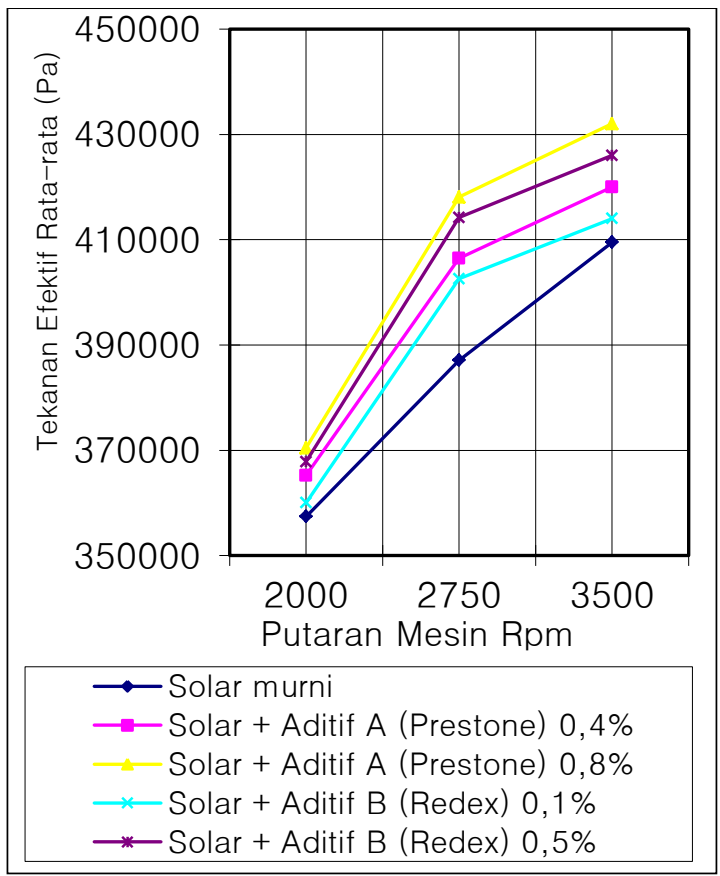

Gambar 3.6. Grafik Tekanan Efektif Rata-Rata $\left(B_{\text {mep }}\right)$ Hasil Perhitungan Pada Mesin.

Dari gambar grafik tersebut dapat dilihat bahwa penambahan aditif pada bahan bakar dengan persentase 0,8\% aditif $\mathrm{A}$ (prestone), tekanan efektif ratarata yang dihasilkan lebih besar, jika dibandingkan persentase di bawahnya dari dua macam aditif tersebut, untuk masing-masing putaran mesin yang sama.
Hasil perhitungan tekanan efektif ratarata $\left(\mathrm{B}_{\text {mep }}\right)$ dapat dilihat dalam tabel 3.14. perhitungan lengkap dapat dilihat pada lampiran.

\subsection{Torsi Teoritis.}

Setelah dilakukan perhitungan dengan rumus maka didapat torsi teoritis dari hasil pengukuran pada Mesin Diesel

\begin{tabular}{|c|l|c|c|c|}
\hline \multirow{2}{*}{ No } & \multirow{2}{*}{$\begin{array}{c}\text { Komposisi } \\
\text { Bahan Bakar }\end{array}$} & \multicolumn{2}{|c|}{ B $_{\text {mep }}$ (Pa) Berbagai Putaran Mesin } \\
\cline { 3 - 5 } & 2000 & $\mathbf{2 7 5 0}$ & $\mathbf{3 5 0 0}$ \\
\hline 1. & Solar murni & $357.391,30$ & $387.096,80$ & $409.500,00$ \\
\hline 2. & $\begin{array}{l}\text { Solar + Aditif B } \\
\text { (Redex) 0,1\% }\end{array}$ & $360.000,00$ & $402.580,64$ & $414.000,00$ \\
\hline 3. & $\begin{array}{l}\text { Solar + Aditif B } \\
\text { (Redex) 0,5\% }\end{array}$ & $367.826,10$ & $414.193,50$ & $426.000,00$ \\
\hline 4. & $\begin{array}{l}\text { Solar + Aditif } \\
\text { A Prestone) }\end{array}$ & $365.217,39$ & $406.451,60$ & $420,000,00$ \\
\hline 0,4\% & $\begin{array}{l}\text { Solar + Aditif } \\
\text { A (Prestone) } \\
\text { 0,8\% }\end{array}$ & $370.434,78$ & $418.064,50$ & $432.000,00$ \\
\hline
\end{tabular}

Robin - Fuji DY23D, sebelum penambahan aditif dan sesudah penambahan aditif, dengan beberapa variasi persentase penambahan aditif dari dua macam aditif yang digunakan. Data tersebut dapat dilihat pada tabel 3.15.

Tabel 3.15. Data hasil perhitungan torsi teoritis.

\begin{tabular}{|c|c|c|c|c|c|c|}
\hline \multirow{3}{*}{ No. } & \multirow{3}{*}{$\begin{array}{c}\text { Putaran } \\
\text { Mesin } \\
\text { (Rpm) }\end{array}$} & \multicolumn{5}{|c|}{$\mathrm{T}_{\mathrm{AP}}(\mathrm{Nm})$ Berbagai komposisi Bahan Bakar } \\
\hline & & \multirow{2}{*}{$\begin{array}{l}\text { Solar } \\
\text { murni }\end{array}$} & \multicolumn{2}{|c|}{$\begin{array}{c}\text { Solar + Aditif } \\
\text { B (Redex) }\end{array}$} & \multicolumn{2}{|c|}{$\begin{array}{c}\text { Solar + Aditif } \\
\text { A (Prestone) }\end{array}$} \\
\hline & & & $0,1 \%$ & $0,5 \%$ & $0,4 \%$ & $0,8 \%$ \\
\hline 1. & 2000 & 6,53 & 6,63 & 6,78 & 6,73 & 6,83 \\
\hline 2. & 2750 & 7,13 & 7,23 & 7,44 & 7,33 & 7,53 \\
\hline 3. & 3500 & 7,44 & 7,55 & 7,75 & 7,66 & 7,86 \\
\hline
\end{tabular}




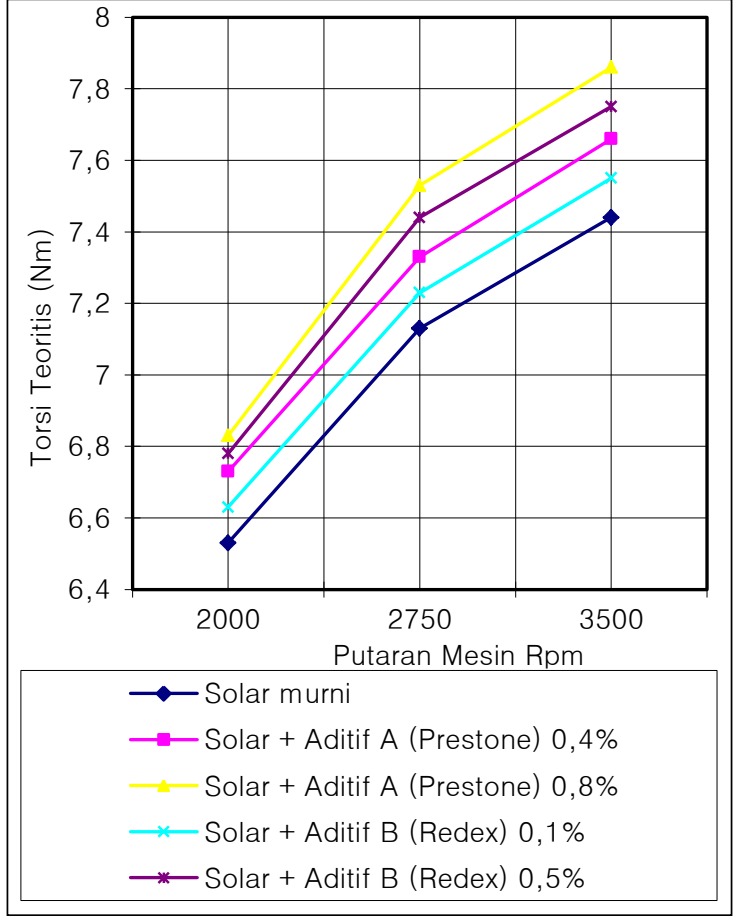

Gambar 3.7. Grafik Torsi Teoritis

Hasil Perhitungan Pada Mesin.

Dari gambar tersebut menunjukan bahwa semakin besar persentase penambahan aditif pada bahan bakar, dari dua macam aditif yang digunakan maka semakin besar torsi teoritis hasil perhitungan yang didapat, untuk masingmasing putaran mesin yang sama. Hasil perhitungan dapat dilihat dalam tabel 3.15. Perhitungan lengkap dilihat pada lampiran.

\section{B. ANALISA DAN PEMBAHASAN}

\subsection{Konsumsi Bahan Bakar}

Besar persentase penambahan aditif pada bahan bakar mesin diesel berpengaruh pada konsumsi bahan bakar. Dari hasil uji terlihat jelas tingkat kehematan bahan bakar pada putaran mesin 2000, 2750 Rpm, dengan besar penambahan aditif bahan baker $0,8 \%$. Tingkat persentase penambahan aditif bahan bakar, perbedaan konsumsi bahan bakarnya sangat jauh, dibandingkan dengan solar murni.

\subsection{Daya Rem}

Besar penambahan aditif bahan bakar persentase $0,8 \% \quad$ Aditif A(prestone), Daya Kuda Rem yang dihasilkan pada putaran mesin 3500 Rpm, lebih besar dibandingkan sebelum ditambah aditif bahan bakar. Aditif yang ditambahkan pada bahan bakar di bawah $0,8 \%$, Daya Kuda Rem yang dihasilkan akan lebih kecil.

\subsection{Efisiensi Panas (Thermal}

\section{Efficiency)}

Penambahan aditif bahan bakar mesin diesel, bahan bakar akan memiliki daya bakar yang lebih besar dibandingkan sebelum ditambah aditif pada bahan bakar, karena pembakaran dalam ruang bakar akan menjadi lebih sempurna. Dari hasil uji didapatkan efisiensi panas mesin diesel menjadi lebih besar sesudah ditambah aditif pada bahan bakar dibandingkan sebelum ditambah aditif pada bahan bakar atau solar murni. 


\subsection{Konsumsi Bahan Bakar Spesifik}

Pada motor diesel penambahan aditif bahan bakar berpengaruh terhadap konsumsi bahan bakar spesifik dibandingkan sebelum ditambah aditif pada bahan bakarnya. Untuk menghasilkan energi tiap $\mathrm{kW} / \mathrm{jam}$ dibutuhkan bahan bakar lebih sedikit, jika besar aditif yang ditambahkan pada bahan bakar 0,8\% A(Prestone). Jumlah aditif yang ditambahkan pada bahan bakar semakin kecil, atau menggunakan solar murni, maka untuk menghasilkan energi tiap $\mathrm{kW} / \mathrm{jam}$ dibutuhkan bahan bakar semakin banyak / lebih boros.

\subsection{Torsi Actual}

Pada mesin diesel, hasil uji torsi yang dihasilkan lebih besar setelah ditambah aditif pada bahan bakarnya, dengan dengan besar aditif $0,8 \%$ A (Prestone). Semakin kecil jumlah aditif yang ditambahkan atau menggunakan solar murni, torsi yang dihasilkan lebih kecil.

\section{Persentase Peningkatan Unjuk Kerja} Motor Diesel-4 Tak

\section{Torsi Actual (Nm)}

\begin{tabular}{|l|c|c|c|c|}
\hline \multirow{2}{*}{ No. } & Rpm & $\begin{array}{c}\text { Sebelum } \\
\text { ditambah } \\
\text { Aditif Bahan } \\
\text { Bakar }\end{array}$ & $\begin{array}{c}\text { Sesudah ditambah } \\
\text { Aditif Bahan } \\
\text { Bakar 0,4\% } \\
\text { A (Prestone) }\end{array}$ & $\begin{array}{c}\text { Kenaikan } \\
(\%)\end{array}$ \\
\hline 1. & 2000 & 6,52 & 6,72 & 3,0 \\
\hline 2. & 2750 & 7,13 & 7,33 & 2,8 \\
\hline 3. & 3500 & 7,43 & 7,65 & 2,9 \\
\hline
\end{tabular}

\begin{tabular}{|c|c|c|c|c|}
\hline No. & Rpm & $\begin{array}{c}\text { Tobelum } \\
\text { ditambah } \\
\text { Aditif Bahan } \\
\text { Bakar }\end{array}$ & $\begin{array}{c}\text { Sesudah ditambah } \\
\text { Aditif Bahan } \\
\text { Bakar 0,8\% } \\
\text { A (Prestone) }\end{array}$ & $\begin{array}{c}\text { Kenaikan } \\
(\%)\end{array}$ \\
\hline 1. & 2000 & 6,52 & 6,83 & 4,7 \\
\hline 2. & 2750 & 7,13 & 7,52 & 5,5 \\
\hline 3. & 3500 & 7,43 & 7,85 & 5,7 \\
\hline
\end{tabular}

\begin{tabular}{|l|c|c|c|c|}
\hline \multirow{2}{*}{ No. } & Rpm & $\begin{array}{c}\text { Sebelum } \\
\text { ditambah } \\
\text { Aditif Bahan } \\
\text { Bakar }\end{array}$ & $\begin{array}{c}\text { Sesudah ditambah } \\
\text { Aditif Bahan } \\
\text { Bakar 0,1\% } \\
\text { B (Redex) }\end{array}$ & $\begin{array}{c}\text { Kenaikan } \\
(\%)\end{array}$ \\
\hline 1. & 2000 & 6,52 & 6,62 & 1,5 \\
\hline 2. & 2750 & 7,13 & 7,22 & 1,3 \\
\hline 3. & 3500 & 7,43 & 7,54 & 1,5 \\
\hline
\end{tabular}

\begin{tabular}{|c|c|c|c|c|}
\hline \multirow{2}{*}{ No. } & \multirow{2}{*}{ Rpm } & $\begin{array}{c}\text { Sebelum } \\
\text { ditambah } \\
\text { Aditif Bahan } \\
\text { Bakar }\end{array}$ & $\begin{array}{c}\text { Sesudah ditambah } \\
\text { Aditif Bahan } \\
\text { Bakar 0,5\% } \\
\text { B (Redex) }\end{array}$ & $\begin{array}{c}\text { Kenaikan } \\
(\%)\end{array}$ \\
\hline 1. & 2000 & 6,52 & 6,78 & 4,0 \\
\hline 2. & 2750 & 7,13 & 7,43 & 4,2 \\
\hline 3. & 3500 & 7,43 & 7,74 & 4,1 \\
\hline
\end{tabular}

1. Daya Kerja Rem (Brake Horse Power)

\begin{tabular}{|l|c|c|c|c|}
\hline \multirow{2}{*}{ No. } & Rpm & $\begin{array}{c}\text { Sebelum } \\
\text { ditambah } \\
\text { Aditif Bahan } \\
\text { Bakar }\end{array}$ & $\begin{array}{c}\text { Sesudah ditambah } \\
\text { Aditif Bahan } \\
\text { Bakar 0,4\% } \\
\text { A (Prestone) }\end{array}$ & $\begin{array}{c}\text { Kenaikan } \\
(\%)\end{array}$ \\
\hline 1. & 2000 & 1,37 & 1,40 & 2,2 \\
\hline 2. & 2750 & 2,05 & 2,10 & 2,4 \\
\hline 3. & 3500 & 2,73 & 2,80 & 2,6 \\
\hline
\end{tabular}

\begin{tabular}{|l|c|c|c|c|}
\hline \multirow{2}{*}{ No. } & Rpm & $\begin{array}{c}\text { Sebelum } \\
\text { ditambah } \\
\text { Aditif Bahan } \\
\text { Bakar }\end{array}$ & $\begin{array}{c}\text { Sesudah (kW) } \\
\text { Aditif Bahan } \\
\text { Bakar 0,8\% } \\
\text { A (Prestone) }\end{array}$ & $\begin{array}{c}\text { Kenaikan } \\
(\%)\end{array}$ \\
\hline 1. & 2000 & 1,37 & 1,42 & 3,6 \\
\hline 2. & 2750 & 2,05 & 2,16 & 5,4 \\
\hline 3. & 3500 & 2,73 & 2,88 & 5,5 \\
\hline
\end{tabular}

\begin{tabular}{|l|c|c|c|c|}
\hline \multirow{2}{*}{ No. } & \multirow{2}{*}{ Rpm } & $\begin{array}{c}\text { Sebelum } \\
\text { ditambah } \\
\text { Aditif Bahan } \\
\text { Bakar }\end{array}$ & $\begin{array}{c}\text { Sesudah ditambah } \\
\text { Aditif Bahan } \\
\text { Bakar 0,5\% } \\
\text { B (Redex) }\end{array}$ & $\begin{array}{c}\text { Kenaikan } \\
(\%)\end{array}$ \\
\hline 1. & 2000 & 1,37 & 1,41 & 2,9 \\
\hline 2. & 2750 & 2,05 & 2,14 & 4,4 \\
\hline 3. & 3500 & 2,73 & 2,84 & 4,0 \\
\hline
\end{tabular}

\section{Waktu Konsumsi Bahan Bakar}

\begin{tabular}{|l|c|c|c|c|}
\hline \multirow{2}{*}{ No. } & Rpm & $\begin{array}{c}\text { Sebelum } \\
\text { ditambah } \\
\text { Aditif Bahan } \\
\text { Bakar }\end{array}$ & $\begin{array}{c}\text { Sesudah ditambah } \\
\text { Aditif Bahan } \\
\text { Bakar 0,4\% } \\
\text { A (Prestone) }\end{array}$ & $\begin{array}{c}\text { Kenaikan } \\
(\%)\end{array}$ \\
\hline 1. & 2000 & 117,35 & 120,15 & 2,4 \\
\hline 2. & 2750 & 81,25 & 83,18 & 2,4 \\
\hline 3. & 3500 & 50,35 & 51,16 & 1,6 \\
\hline
\end{tabular}




\begin{tabular}{|l|c|c|c|c|}
\hline \multirow{2}{*}{ No. } & Rpm & $\begin{array}{c}\text { Sebelum } \\
\text { ditambah } \\
\text { Aditif Bahan } \\
\text { Bakar }\end{array}$ & $\begin{array}{c}\text { Sesudah ditambah } \\
\text { Aditif Bahan } \\
\text { Bakar 0,8\% } \\
\text { A (Prestone) }\end{array}$ & $\begin{array}{c}\text { Kenaikan } \\
(\%)\end{array}$ \\
\hline 1. & 2000 & 117,35 & 123,36 & 5,1 \\
\hline 2. & 2750 & 81,25 & 85,27 & 4,9 \\
\hline 3. & 3500 & 50,35 & 52,53 & 4,3 \\
\hline
\end{tabular}

\begin{tabular}{|l|c|c|c|c|}
\hline \multirow{2}{*}{ No. } & Rpm & $\begin{array}{c}\text { Sebelum } \\
\text { ditambah } \\
\text { Aditif Bahan } \\
\text { Bakar }\end{array}$ & $\begin{array}{c}\text { Sesudah ditambah } \\
\text { Aditif Bahan } \\
\text { Bakar 0,1\% } \\
\text { B (Redex) }\end{array}$ & $\begin{array}{c}\text { Kenaikan } \\
(\%)\end{array}$ \\
\hline 1. & 2000 & 117,35 & 119,25 & 1,6 \\
\hline 2. & 2750 & 81,25 & 82,27 & 1,2 \\
\hline 3. & 3500 & 50,35 & 50,78 & 0,9 \\
\hline
\end{tabular}

\begin{tabular}{|l|c|c|c|c|}
\hline \multirow{2}{*}{ No. } & Rpm & $\begin{array}{c}\text { Sebelum } \\
\text { ditambah } \\
\text { Aditif Bahan } \\
\text { Bakar }\end{array}$ & $\begin{array}{c}\text { Wesudah ditambah } \\
\text { Aditif Bahan } \\
\text { Bakar 0,5\% } \\
\text { B (Redex) }\end{array}$ & $\begin{array}{c}\text { Kenaikan } \\
(\%)\end{array}$ \\
\hline 1. & 2000 & 117,35 & 121,14 & 3,2 \\
\hline 2. & 2750 & 81,25 & 84,14 & 3,5 \\
\hline 3. & 3500 & 50,35 & 51,95 & 3,8 \\
\hline
\end{tabular}

\section{Konsumsi Bahan Bakar Spesifik}

\begin{tabular}{|l|c|c|c|c|}
\hline \multirow{2}{*}{ No. } & Rpm & $\begin{array}{c}\text { Sebelum } \\
\text { ditambah } \\
\text { Aditif Bahan } \\
\text { Bakar }\end{array}$ & $\begin{array}{c}\text { Sesudah ditambah } \\
\text { Aditif Bahan } \\
\text { Bakar 0,4\% } \\
\text { A (Prestone) }\end{array}$ & $\begin{array}{c}\text { Kenaikan } \\
(\%)\end{array}$ \\
\hline 1. & 2000 & 0,15 & 0,14 & 7,1 \\
\hline 2. & 2750 & 0,15 & 0,14 & 7,1 \\
\hline 3. & 3500 & 0,16 & 0,16 & 0 \\
\hline
\end{tabular}

\begin{tabular}{|c|c|c|c|c|}
\hline \multirow{2}{*}{ No. } & Rpm & $\begin{array}{c}\text { Sebelum } \\
\text { ditambah } \\
\text { Aditif Bahan } \\
\text { Bakar }\end{array}$ & $\begin{array}{c}\text { Sesfo } \mathbf{~} \text { (kg/kWh) } \\
\text { Aditif Bahan } \\
\text { Bakar 0,8\% } \\
\text { A (Prestone) }\end{array}$ & $\begin{array}{c}\text { Kenaikan } \\
(\%)\end{array}$ \\
\hline 1. & 2000 & 0,15 & 0,13 & 15,4 \\
\hline 2. & 2750 & 0,15 & 0,13 & 15,4 \\
\hline 3. & 3500 & 0,16 & 0,16 & 0 \\
\hline
\end{tabular}

\begin{tabular}{|c|c|c|c|c|}
\hline \multirow{2}{*}{ No. } & Rpm & $\begin{array}{c}\text { Sebelum } \\
\text { ditambah } \\
\text { Aditif Bahan } \\
\text { Bakar }\end{array}$ & $\begin{array}{c}\text { Sesudah ditambah } \\
\text { Aditif Bahan } \\
\text { Bakar 0,1\% } \\
\text { B (Redex) }\end{array}$ & $\begin{array}{c}\text { Kenaikan } \\
(\%)\end{array}$ \\
\hline 1. & 2000 & 0,15 & 0,14 & 7,1 \\
\hline 2. & 2750 & 0,15 & 0,14 & 7,1 \\
\hline 3. & 3500 & 0,16 & 0,16 & 0 \\
\hline
\end{tabular}

\begin{tabular}{|c|c|c|c|c|}
\hline \multirow{2}{*}{ No. } & \multirow{2}{*}{ Rpm } & $\begin{array}{c}\text { Sebelum } \\
\text { ditambah } \\
\text { Aditif Bahan } \\
\text { Bakar }\end{array}$ & $\begin{array}{c}\text { Sesudah ditambah } \\
\text { Aditif Bahan Bakar } \\
0,5 \% \\
\text { B (Redex) }\end{array}$ & $\begin{array}{c}\text { Kenai } \\
\text { kan } \\
(\%)\end{array}$ \\
\hline 1. & 2000 & 0,15 & 0,14 & 7,1 \\
\hline 2. & 2750 & 0,15 & 0,14 & 7,1 \\
\hline 3. & 3500 & 0,16 & 0,16 & 0 \\
\hline
\end{tabular}

\section{Nilai Ekonomi Penambahan Aditif}

\section{Bahan Bakar Diesel}

\begin{tabular}{|c|c|c|c|c|c|c|c|}
\hline \multirow{2}{*}{$\mathrm{N}$} & \multirow{2}{*}{$\mathrm{Rpm}$} & \multicolumn{6}{|c|}{ Waktu Konsumsi Bahan Bakar } \\
\cline { 3 - 7 } $\mathrm{o}$ & $\begin{array}{c}\text { Solar } \\
\text { Murni }\end{array}$ & $\begin{array}{c}\text { Solar + } \\
0,4 \% \\
\text { A } \\
\left(\begin{array}{c}\text { Presto } \\
\text { ne) }\end{array}\right.\end{array}$ & $\begin{array}{c}\text { Selisih } \\
\text { (Detik) }\end{array}$ & $\begin{array}{c}\text { Daya } \\
\text { Hemat } \\
\text { Perlite } \\
\mathrm{r} \\
(\mathrm{ml})\end{array}$ & $\begin{array}{c}\text { Harga } \\
\text { Daya } \\
\text { Hemat } \\
\text { Perlite } \\
\mathrm{r}(\mathrm{Rp})\end{array}$ & $\begin{array}{c}\text { Harga } \\
\text { Solar + } \\
\text { Aditif } \\
\text { Perlite } \\
\mathrm{r}(\mathrm{Rp})\end{array}$ \\
\hline 1 & 2000 & 117,35 & 120,15 & 2,80 & 24 & 108 & \multirow{2}{*}{900} \\
\hline 2 & 2750 & 81,25 & 83,18 & 1,93 & 24 & 108 & \\
\hline 3 & 3500 & 50,35 & 51,16 & 0,81 & 16 & 72 & \\
\hline
\end{tabular}

\begin{tabular}{|c|c|c|c|c|c|c|c|}
\hline \multirow[b]{2}{*}{$\begin{array}{l}\mathrm{N} \\
\mathrm{o}\end{array}$} & \multirow[b]{2}{*}{ Rpm } & \multicolumn{6}{|c|}{ Waktu Konsumsi Bahan Bakar } \\
\hline & & $\begin{array}{l}\text { Solar } \\
\text { Murni }\end{array}$ & $\begin{array}{c}\text { Solar + } \\
0,8 \% \\
\text { A } \\
\text { (Presto } \\
\text { ne) }\end{array}$ & $\begin{array}{l}\text { Selisin } \\
\text { (Detik) }\end{array}$ & $\begin{array}{c}\text { Daya } \\
\text { Hemat } \\
\text { Perlite } \\
\text { r } \\
(\mathrm{ml})\end{array}$ & $\begin{array}{c}\text { Harga } \\
\text { Daya } \\
\text { Hemat } \\
\text { Perlite } \\
\text { r (Rp) }\end{array}$ & $\begin{array}{c}\text { Harga } \\
\text { Solar + } \\
\text { Aditif } \\
\text { Perlite } \\
\text { r (Rp) }\end{array}$ \\
\hline 1 & 2000 & 117,35 & 123,36 & 6,01 & 51 & 230 & \\
\hline 2 & 2750 & 81,25 & 85,27 & 4,02 & 49 & 220 & 1.800 \\
\hline 3 & 3500 & 50,35 & 52,53 & 2,88 & 43 & 193 & \\
\hline
\end{tabular}

Catatan :

$\checkmark$ Harga solar Rp. 4.500/liter $=$ Rp.

$4,5 / \mathrm{ml}$

$\checkmark$ Harga Aditif A(Prestone) Rp.

$45.000 / 200 \mathrm{ml}=$ Rp. $225 / \mathrm{ml}$

\begin{tabular}{|c|c|c|c|c|c|c|c|}
\hline \multirow[b]{2}{*}{$\begin{array}{l}\mathrm{N} \\
\mathrm{o}\end{array}$} & \multirow[b]{2}{*}{$\begin{array}{c}\mathrm{Rp} \\
\mathrm{m}\end{array}$} & \multicolumn{6}{|c|}{ Waktu Konsumsi Bahan Bakar } \\
\hline & & $\begin{array}{l}\text { Solar } \\
\text { Murni }\end{array}$ & $\begin{array}{c}\text { Solar + } \\
0,1 \% \\
\text { A } \\
\text { (Presto } \\
\text { ne) }\end{array}$ & $\begin{array}{l}\text { Seli } \\
\text { sih } \\
\text { (De } \\
\text { tik) }\end{array}$ & $\begin{array}{c}\text { Daya } \\
\text { Hemat } \\
\text { Perlite } \\
\quad \mathrm{r} \\
(\mathrm{ml})\end{array}$ & $\begin{array}{c}\text { Harga } \\
\text { Daya Hemat } \\
\text { Perliter (Rp) }\end{array}$ & $\begin{array}{c}\text { Harga } \\
\text { Solar + } \\
\text { Aditif } \\
\text { Perlite } \\
\text { r (Rp) }\end{array}$ \\
\hline 1 & $\begin{array}{c}200 \\
0\end{array}$ & 117,35 & 119,25 & $\begin{array}{c}1,9 \\
0\end{array}$ & 16 & 72 & \\
\hline 2 & $\begin{array}{c}275 \\
0\end{array}$ & 81,25 & 82,27 & $\begin{array}{c}1,0 \\
2\end{array}$ & 12 & 54 & 300 \\
\hline 3 & $\begin{array}{c}350 \\
0\end{array}$ & 50,35 & 50,78 & $\begin{array}{c}0,4 \\
3\end{array}$ & 9 & 41 & \\
\hline
\end{tabular}

\begin{tabular}{|c|c|c|c|c|c|c|c|}
\hline \multirow[b]{2}{*}{ No. } & \multirow[b]{2}{*}{$\begin{array}{l}\mathrm{Rp} \\
\mathrm{m}\end{array}$} & \multicolumn{6}{|c|}{ Waktu Konsumsi Bahan Bakar } \\
\hline & & $\begin{array}{l}\text { Solar } \\
\text { Murni }\end{array}$ & $\begin{array}{c}\text { Solar } \\
+ \\
0,5 \% \\
\text { A } \\
\text { (Prest } \\
\text { one) }\end{array}$ & $\begin{array}{l}\text { Sel } \\
\text { isih } \\
\text { (D } \\
\text { eti } \\
\text { k) }\end{array}$ & $\begin{array}{c}\text { Day } \\
\text { a } \\
\mathrm{He} \\
\text { mat } \\
\text { Perl } \\
\text { iter }\end{array}$ & $\begin{array}{c}\text { Harga } \\
\text { Daya } \\
\text { Hemat } \\
\text { Perliter } \\
\text { (Rp) }\end{array}$ & $\begin{array}{c}\text { Harga } \\
\text { Solar } \\
+ \\
+ \\
\text { Aditif } \\
\text { Perlite } \\
\text { r (Rp) }\end{array}$ \\
\hline
\end{tabular}




\begin{tabular}{|c|c|c|c|c|c|c|c|}
\hline & & & & & $(\mathrm{ml})$ & & \\
\hline \multirow{2}{*}{1.} & $\begin{array}{c}20 \\
00\end{array}$ & $\begin{array}{c}117,3 \\
5\end{array}$ & $\begin{array}{c}121,1 \\
4\end{array}$ & $\begin{array}{c}3,7 \\
9\end{array}$ & 32 & 114 & \\
\cline { 1 - 6 } 2. & $\begin{array}{c}27 \\
50\end{array}$ & 81,25 & 84,14 & $\begin{array}{c}2,8 \\
9\end{array}$ & 35 & 158 & \multirow{2}{*}{1.500} \\
\cline { 1 - 5 } 3. & $\begin{array}{c}35 \\
0\end{array}$ & 50,35 & 51,95 & $\begin{array}{c}1,6 \\
0\end{array}$ & 38 & 176 & \\
\cline { 1 - 5 } & 0
\end{tabular}

Catatan :

$\checkmark$ Harga solar Rp. 4.500/liter $=$ Rp. $4,5 / \mathrm{ml}$

$\checkmark$ Harga Aditif B (Redex) Rp. $15.000 / 50 \mathrm{ml}=\mathrm{Rp} .300 / \mathrm{ml}$

\section{KESIMPULAN DAN SARAN}

\section{Kesimpulan}

Berdasarkan hasil percobaan yang dilakukan secara teoritis dan data-data aktual di lapangan yang didapat sebelum penambahan aditif dan sesudah penambahan aditif pada bahan bakar, maka penulis menarik kesimpulan:

1. Penambahan aditif pada bahan bakar solar mesin diesel, dapat meningkatkan unjuk kerja mesin diesel

2. Semakin besar jumlah aditif yang ditambahkan pada bahan bakar mesin diesel, maka semakin tinggi peningkatan unjuk kerjanya dibandingkan bahan bakar solar murni

3. Dua macam aditif yang digunakan paling bagus adalah A (Prestone) dengan persentase penambahan $0,8 \%$, dari berbagai putaran mesin.

\section{DAFTAR PUSTAKA}

Arismunandar, W. \& Tsuda, K. 1975. “ Motor Diesel Putaran Tinggi" Penerbit P.T. Pradnya Paramita. Jakarta.

Boenarto, 1995. "Praktek Keterampilan Motor Diesel Mobil" Penerbit C.V. Aneka. Solo.

Culp, A. W., 1996. "Perinsipperinsip Konversi Energi" Penerjemah Darwin Sitompul. Penerbit Erlangga.

Daryanto, 2004. "Motor Diesel pada Mobil" Penerbit C.V. Yrama Widya. Bandung.

Mitsubishi Training Center Departemen. Penerbit P.T. Krama Yuda Tiga Berlian Motors. Jakarta.

Sukoco \& Arifin Zainal. 2008. "Teknologi Motor Diesel" Penerbit Alfabeta. Bandung Toyota Astra Training Manual Diesel Engine. Tecquipment Limited, "TD110 - TD115 Mini Engine Test Rings ang Instrumentation", England.

Usman, R. \& Sardjijo. 1979. "Motor Bakar 3" Penerbit P.T. Anem Kosong Anem.

Wardono H. 2004 " Modul Pembelajaran Motor Bakar 4Langkah ", Jurusan Tekn ik Mesin - Universitas Lampung, Bandar Lampung. 